\title{
Література:
}

1. Гончаренко С.У. Український педагогічний словник / гол. ред. С. Головко. К.: Либідь, 1997. 376 с.

2. Иванова В.И. Акмеологическая концепция формирования образовательной среды подготовки специалистов : дис. ... д-ра пед. наук : 19.00.13. Москва, 2009. 662 с.

3. Маркова А.К. Психология профессионализма. М.: Междунар. гуманит. фонд «Знание», 1996. 308 с.

4. Сисоєва С. Професійна підготовка в контексті особистісноорієнтованої парадигми освіти. Педагог професійної школи : зб. наук. пр. / упоряд.: Н.Г. Ничкало, О.І. Щербак. К.: Науковий світ, 2003. Вип. 5. С. 20-24.

DOI https://doi.org/10.30525/978-9934-588-80-8-2.5

\section{РОЗВИТОК ІНШОМОВНОЇ КОМУНІКАТИВНОЇ КОМПЕТЕНЦІЇ КУРСАНТІВ 3 ВИКОРИСТАННЯМ ТЕХНОЛОГІЙ ДИСТАНЦІЙНОГО НАВЧАННЯ}

\author{
Дроб Н. Ч. \\ старший науковий співробітник \\ навчально-наукового центру мовної підготовки \\ Харківський начіональний університет \\ Повітряних Сил імені Івана Кожедуба
}

Федорчук А. С.

науковий співробітник навчально-наукового ценнтру мовної підготовки

Харківський національний університет

Повітряних Сил імені Івана Кожедуба

м. Харків, Украӥна

Модернізація системи вищої військової освіти та умови сьогодення передбачають активний розвиток використання дистанційної освіти форми навчання, під час якого взаємодія викладача та того, хто навчається - курсанта, а також курсантів між собою здійснюється на відстані та відображає всі притаманні навчальному процесу компоненти (цілі, зміст, методи, організаційні форми, засоби навчання), що реалізуються специфічними засобами мультимедійних технологій, 
мережі Інтернет або іншими засобами, що передбачають інтерактивність.

Оскільки пріоритетним напрямком навчання англійської мови військовослужбовців сучасної освіти $є$ розвиток іншомовної комунікативної компетенції, використання технологій дистанційного навчання найкращим чином сприяє цьому під час навчання англійської мови як загальновживаного, так і професійного спрямування та надає широкі можливості військовослужбовцям, що знаходяться навіть у віддалених військових частинах, підвищувати або підтримувати свій рівень знання англійської мови.

Концепція розвитку дистанційної освіти в Україні визначає, що «Дистанційна освіта - це форма навчання, рівноцінна 3 очною, вечірньою, заочною та екстернатом, що реалізується, в основному, за технологіями дистанційного навчання» [1]. В свою чергу, технології дистанційного навчання містять у своєму складі педагогічні та інформаційні технології.

Серед найбільш поширених прийомів використання технологій дистанційного навчання можна назвати наступні: навчальні комп'ютерні програми, використання соціальних мереж, електронної пошти, електронної дошки оголошень, скайпу, проведення відеоконференцій, розробка і реалізація курсів в різних системах.

Все більш задіяними стають Системи управління навчанням (Learning Management System, LMS) - програмні додатки для адміністрування навчальних курсів в рамках дистанційної освіти або платформи для електронного навчання (e-learning). За допомогою LMS можливо створити єдину базу навчальних електронних курсів та навчальних матеріалів, керувати навчальним процесом та тими, хто навчається, забезпечувати доступ до навчальних ресурсів та оцінювати результати.

Прикладами LMS є віртуальне середовище навчання Schoology послуга соціальних мереж для шкільних та вищих навчальних закладів, яка дозволяє користувачам створювати навчальні ресурси, оперувати ними та ділитися навчальним вмістом. Або віртуальне середовище Google Classroom, яке значно спрощує та покращує комунікаційні процеси між викладачем та курсантами за допомогою встановлених налаштувань. Одна 3 головних переваг таких веб-сервісів безпаперовий шлях обміну матеріалом між викладачем і курсантом та поширення завдань та додаткової інформації.

Треба відмітити систему MOODLE (Modular Object-Oriented Dynamic Learning Environment), що активно діє i в нашому університеті, в ресурсі якої викладачі англійської мови створюють 24 
навчальні курси в дистанційному форматі. Прикладами таких є «Курс стандартної фразеології радіообміну англійською мовою для льотного складу та груп керівництва польотами», курс «Aviation English», «Курс для підготовки до складання тесту за стандартами ICAO» тощо, розроблені педагогічним складом кафедри авіаційної англійської мови університету. Таки курси мають на меті надати можливість військовослужбовцям за місцем служби самостійно у зручний для них час опанувати спеціалізовану англійську мову, підвищити професійну комунікативну компетенцію.

Добре себе зарекомендував електронний продукт English Discoveries, що $є$ спільною розробкою компаній Edusoft та Berlitz International. Цей насичений мультімедіакурс, призначений виключно для навчальних закладів, складається 3 п'яти рівнів за складністю та охоплює всі граматичні конструкції англійської мови та понад 3500 лексичних одиниць.

Продовжують набирати популярність мовні соціальні мережі, які дозволяють вивчати іноземну мову самостійно. Такі мережі можна класифікувати за спеціалізацією, доступністю інформації та географічною ознакою [3, с. 4]. Досвід роботи свідчить про позитивну динаміку використання в системі дистанційного навчання та самоосвіти таких мовних соціальних мереж як Lang-8, Interpals, Sharedtalk, Livemocha, Omegle, Mylanguageexchange, Italki, Busuu, та інтерактивних інтернет-сервісів, як, наприклад, LinguaLeo або канали YouTube для тих, хто вивчає англійську мову, та ін. Використання даних ресурсів в освітньому процесі дозволяє, 3 одного боку, організувати практику спілкування з носієм мови (дистанційно), а 3 іншого боку, удосконалювати мовну компетенцію, письмові навички курсантів та підвищувати мотивацію до вивчення іноземних мов.

Простий у використанні та результативний прийом технології дистанційного навчання - електронна пошта, зручність якого обумовлюється асинхронним режимом обміну повідомленнями: текстовими i графічними, аудіо- і відеофрагментами. Оскільки електронна пошта не вимагає одночасного перебування за комп'ютерами кореспондента i адресата, вона надає викладачеві можливість дистанційно здійснювати індивідуально-особистісне навчання, забезпечуючи курсанта каналом зворотного зв'язку, без якого процес навчання не може бути повноцінним [2, с. 78].

Електронна дошка оголошень - прийом дистанційного навчання іноземним мовам, що дозволяє кожному користувачеві помістити на неї своє оголошення і прочитати оголошення інших. Електронна дошка часто створюється в рамках електронної конференції і служить для 
вирішення організаційних завдань, що виникають під час навчального процесу. При дистанційному навчанні електронна дошка оголошень використовується, наприклад, для організації навчальних груп за інтересами та рівнем здібностей [2, с. 80$]$.

Ще одна можливість дистанційного навчання, що виникла у результаті розвитку електронних технологій, - навчання іноземної мови по скайпу (Skype - програмне забезпечення для текстового, голосового та відеозв'язку через мережу Інтернет між комп'ютерами). Завдяки можливості використовувати різні рівні складності навчальних програм у відповідності до базового рівня знань слухача, відсутності необхідності у самостійній роботі над правильною вимовою та складними граматичними конструкціями завдяки постійному контролю та допомозі висококваліфікованих викладачів, відсутності залежності від місця проведення занять, застосуванню всіх найсучасніших i прогресивних технологій педагогіки, ця методика визнана високорезультативною як слухачами, так і викладачами.

Навчальний процес на основі використання дистанційних технологій навчання також включає в себе роботу з електронним підручником -використовується для самостійного опрацювання теоретичного матеріалу 3 дисципліни; вебінари - особливий вид відеоконференцій, що одночасно забезпечує двосторонню передачу, обробку, перетворення й подання інтерактивної інформації на відстані (вебінари більше використовуються для донесення навчального матеріалу, тому ще в цій системі мінімізовано зворотній зв'язок 3 аудиторією); чат-конференції - використовуються для дискусій, обговорення проблемних питань, також з метою короткої звітності про виконану роботу та 3 метою надання групових й індивідуальних консультацій; он-лайн-конференції (наприклад, на платформі ZOOM), що дозволяють повноцінний обмін інформацією між викладачем та курсантом у режимі реального часу; тематичні форуми, де можна залишити запитання й коментарі під час опанування навчального матеріалу.

Дистанційне навчання - це форма активної діяльності курсанта 3 освоєння іноземної мови, технології та методи якої активно розвиваються. Наявність величезної кількості сучасних прийомів навчання іноземним мовам в дистанційному форматі дозволяє зробити навчальний процес не тільки цікавим, але і продуктивним. Однак у застосуванні всього різноманітного спектру прийомів та технологій дистанційного навчання існуе ще потрібність як у ретельно розробленій, цілісній методиці дистанційного навчання іноземної мови загалом, так і у методиці формування окремих компонентів загально26 
вживаної та професійно-спрямованої іншомовної комунікативної компетенції.

\title{
Література:
}

1. Концепція розвитку дистанційної освіти в Україні. (Затверджено Постановою МОН України від 20 грудня 2000 р.) [Електронний pecypc]: http://www.osvita.org.ua/distance/pravo/00.html

2. Белянина М.В. Дистанционное обучение иностранному языку в неязыковом вузе // Гуманитарное образование: история, традиции, перспективы: сборник научных трудов. Выпуск 3. Елец: ЕГУ им. И.А. Бунина, 2014. 77-82 с.

3. Шарифулина А.А. Языковые социальные сети в обучении английскому языку. [Електронний pecypc]: http://sci-article.ru/stat. php?i=1411295694

DOI https://doi.org/10.30525/978-9934-588-80-8-2.6

\section{DEVELOPING COMMUNICATION SKILLS OF STUDENTS OF HUMANITARIAN AND NATURAL SPECIALTIES AS A SOFT SKILL IN THE PROCESS OF TRAINING}

\author{
Zhukova O. A. \\ Doctor of Pedagogical Sciences, Associate Professor, \\ Head of Pedagogy Department \\ V. N. Karazin Kharkiv National University \\ Kharkiv, Ukraine
}

Trainings are one of the most spread forms of work with students. They are studied by modern scientists in broad and narrow meanings [16: p. 287]. Studying training in a broad sense allows us to evaluate it as a form of work with a groupto take into account external and internal factors, objective and subjective conditions in the process of interaction between the teacher and the participants [4]. If the researcher views training as a program of various systematically carried out actions to develop certain qualities, attitudes, abilities and skills [2: p.15; 13: p. 70], there is a need for studying it in a narrow perspective.

The narrow context of perception of this form of interaction in the formal and informal segments of the educational system makes it possible for the teacher as the organizer of the training to specify goal setting and, according to the taxonomy of B. Bloom's goals [19], to trace the correspondence of 